\title{
Dhamiāk and BakrāLa
}

On March 13 (or 15), 1206, Sultan Muizuddin Ghuri was mortally wounded by some robbers at Damyek, on his return from India, after putting down a rising that had taken place in the Punjab, headed by the Khokars and the Rai Sal, of the Koh-i-Jud (Salt Range).

Last winter (1907-8) I was able to identify the scene of the tragedy. It took place close to the village (of the present time) of Dhamiāk, where the well-used road from Rohtās to Râwalpindi ascended from the bed of the Bakrāla stream to the plateau of the Pothwār (Pat-hār ?).

In February (1908) my wife and I were at the headquarters of the Iskandrāl sept of the Gakkars, and the Chiefs, Rajah Ali Haider Khan Bahadur (Ressaldar Major of the Central India Horse), then on leave, and Fazaldād Khan, a retired Subadar Major (1st class of the Order of British India), told me the following story.

The Ghuri troops were encamped for the night at Dhamiāk, and a party of Gakkars in the darkness stole up through the ravines and brushwood, eluded the sentinels, and entered the Royal Pavilions. Their object was plunder. They were, however, discovered; and in the melée one of them stabbed and mortally wounded the Sultan, who had personally engaged them.

Dhamiāk is to-day a township in the Jhelam District. The place where the Sultan's camp was placed and where the tragedy took place is still pointed out. Men also point out the inclined plane leading from the bottom of the ravine, which was used till the construction of the Grand Trunk Road. This particular track was the only one in the whole country suited for wheeled traffic, and Ranjit Singh's guns and the artillery of the Moghal emperors used to be dragged along the stream and up by strong teams of bullocks.

On referring to the translation of the Tabakāt-i-Näsiri 
I find that the late Major Raverty, in his exhaustive notes, had not identified the scene of this occurrence.

The winding bed of the stream between the villages of Bakrāla and Dhamiāk was the road by which for countless centuries invading armies had entered and left the Punjab when they did not use the Nilāb-Bhera route.

Bakrāla is the Bhakrā of Jahangir's itinerary (march to Kabul, 1606-Tūzuk-i-Jahanngīrì). He states that in the Gakkar dialect the name signified a forest or jungle. The stream bed along which the royal cortége marched was fringed with oleanders, and the Palās was in full bloom between Bhakrā and Sahā (or Sihā); on the plateau of the Pothwār the jungle of Palās has disappeared. The place Sahă or Sihā was some 2 miles beyond Dhamiāk. This ill-omened place would naturally be avoided by the royal retinue.

There was a shorter route, from Rohtās to the Bauli (near the village of Khojki), constructed by Sher Shah, thence to Ratyāl, and following the line of the Grand Trunk Road to the point where it crosses the Bakrāla stream by the (modern) bridge. The country along the right bank was too difficult for the Engineers of the sixteenth century, and the Bakräla stream afforded the only means of access to the plateau.

The remains of a very large sarai near Rohtās on the left bank of the Khän stream marks the site of the camping-ground. The sarai shelters at present a colony of Arains (mālis), who claim to have always oceupied the land since the "time of Sher Shäh". The sarai is now called Rājo Pindi and less frequently Jhanda ka Sarai. It is a picturesque ruin. The masjid and well inside the enclosure are in good preservation; the latter in full use.

G. TAte. 